\title{
Characterization of a Partial cDNA Clone for the NILE Glycoprotein and Identification of the Encoded Polypeptide Domain
}

\author{
John T. Prince, Nina Milona, and William B. Stallcup \\ La Jolla Cancer Research Foundation, La Jolla, California 92037
}

\begin{abstract}
A partial cDNA clone [2.4 kilobase (kb)] for the nerve growth factor-inducible large external (NILE) glycoprotein was selected from a $\lambda$ gt11 expression library constructed using mRNA from PC12 cells. A 0.2 kb subclone (pNILE-1B) was used for Northern blot analysis of NILE message present in 2 NILE-positive neuronal cell lines and 2 NILE-negative glial cell lines. pNILE-1B hybridizes with components of 6.8 and $2.0 \mathrm{~kb}$ in the 2 neuronal cell lines but fails to show hybridization with any components in the 2 glial cell lines. Only the $6.8 \mathrm{~kb}$ species would be large enough to code for the NILE polypeptide. A rabbit antiserum was prepared against the NILE- $\beta$-galactosidase fusion protein produced by the NILE clone. This antiserum (anti-NILE- $\beta$-gal) immunoprecipitates NILE glycoprotein from neuronal cell lines, further confirming the authenticity of the NILE cDNA clone. The epitope recognized by anti-NILE- $\beta$-gal is contained in an $85 \mathrm{kDa}$ tryptic fragment from the phosphorylated carboxy terminus of NILE. The $160 \mathrm{kDa}$ tryptic fragment containing the amino terminus is not recognized by anti-NILE- $\beta$-gal. Both immunoprecipitation and immunofluorescence experiments indicate that the anti-NILE- $\beta$-gal epitope is not exposed on the cell surface but is accessible only after cells are treated with detergent. The cytoplasmic nature of the determinant is also indicated by its absence on a truncated, soluble form of NILE released from cells (possibly by a proteolytic mechanism) into the medium. This released NILE is 15-20 kDa smaller than the detergent-extracted NILE and, in addition to lacking the antiNILE- $\beta$-gal epitope, does not contain the cytoplasmic site(s) of phosphorylation. Nucleotide sequencing of the pNILE-1B subclone confirms the location of the anti-NILE- $\beta$-gal epitope in the cytoplasmic domain. The clone contains an open reading frame coding for a 79 amino acid segment of the polypeptide that differs in only 2 residues from the cytoplasmic domain of the L1 glycoprotein.
\end{abstract}

The nerve growth factor-inducible large external (NILE) glycoprotein, first identified as a cell-surface component of $\mathrm{PC} 12$ cells (McGuire et al., 1978), has been shown to be present on many types of neuronal cell lines and neurons in primary culture (Salton et al., 1983a, b; Stallcup et al., 1983; Stallcup and Beas-

Received Apr. 25, 1988; revised July 20, 1988; accepted July 21, 1988.

This work was supported by NIH Grant NS 23126 to W.B.S. We wish to thank Drs. J. Boulter and J. Patrick for the generous gift of their PC 12 cDNA library in $\lambda \mathrm{gt} 11$ and Dr. M. Schachner for providing us with antibody against Ll glycoprotein.

Correspondence should be addressed to Dr. William B. Stallcup, La Jolla Cancer Rescarch Foundation, 10901 N. Torrcy Pincs Road, La Jolla, CA 92037.

Copyright (C) 1989 Society for Neuroscience $0270-6474 / 89 / 051825-10 \$ 02.00 / 0$ ley, 1985b). In vivo NILE is expressed on axonal projections in developing nerve fiber tracts of the rat CNS and appears to serve an adhesive function in the fasciculation of axons in the tracts (Stallcup and Beasley, 1985a; Stallcup et al., 1985; Beasley and Stallcup, 1987). The molecules L1 and Ng-CAM are immunologically and structurally related to NILE (Bock et al., 1985; Friedlander et al., 1986; Sajovic et al., 1986) and serve similar adhesive functions in the mouse and chicken nervous systems, respectively (Grumet et al., 1984b; Rathjen and Schachner, 1984; Keilhauer et al., 1985; Hoffman et al., 1986). The NILE:L1:NgCAM family of molecules is distinct from the neural cell adhesion molecule (N-CAM) not only structurally (Faissner et al., 1984a; Grumet et al. 1984a; Rathjen and Rutishauser, 1984; Stallcup and Beasley, 1985b), but also in cellular distribution (Faissner et al., 1984b; Rathjen and Rutishauser, 1984; Rathjen and Schachner, 1984; Thiery et al., 1985; Daniloff et al., 1986; Beasley and Stallcup, 1987). While N-CAM is widely distributed on multiple neural cell types, both mature and immature, NILE: $\mathrm{L} 1: \mathrm{Ng}-\mathrm{CAM}$ molecules are much more tightly restricted to developing nerve fiber tracts and are thus well suited to scrve as specific mediators of adhesion among axons.

In order to understand how the NILE:L1:Ng-CAM class of glycoproteins function in adhesive interactions, it will be necessary to elucidate the structural characteristics of the molecule, define the organization of its various domains with respect to the cell membrane, and understand how expression of the molecule is controlled during development. Toward these ends we have undertaken molecular cloning of the NILE gene, a project that can ultimately yield both structural data and information about the regulation of expression. In this initial study we describe the isolation of a partial cDNA clone for NILE from a $\lambda \mathrm{gt} 11$ expression library and the use of this clone to identify NILE mRNA species in cloned neural cell lines. We also describe the preparation of an antiserum against the NILE- $\beta$-galactosidase fusion protein produced by this clone and the characterization of the polypeptide domain recognized by this antiserum.

\section{Materials and Methods}

Cell lines. For our studies, we used 4 neuronal cell lines-IMR-32 (Tumilowicz et al., 1970), PC12 (Greene and Tischler, 1976), B35 (Schubert et al., 1974), C1300 cl. N18 (Amano et al., 1972)-and 2 non-neuronal cell lines-B9 and B92 (Schubert et al., 1974). B9, B92, IMR-32, B35, and $\mathrm{C} 1300 \mathrm{cl}$. N18 were maintained in Dulbecco's modified Eagle's medium (DMEM) containing 10\% fetal calf serum. PC12 cells were grown in DMEM containing 10\% horse serum and 5\% fetal calf serum.

Molecular cloning. A PC12 cDNA library in $\lambda \mathrm{gt} 11$ was obtained as a gift from J. Boulter and J. Patrick, the Salk Institute (Boulter et al., 1986). The $\lambda$ NILE- 1 clone described in our work was isolated from the library using immunochemical screening techniques (Huynh et al., 1985). 
Specifically, we used a rabbit antiserum against the L1 glycoprotein (Rathjen and Schachner, 1984) for selecting NILE-positive clones for further purification and study.

For subcloning, $\lambda$ NILE- 1 DNA was purified as described by Maniatis et al. (1982). The phage DNA was digested by Eco RI (BRL) and introduced into the plasmid pGEM-3 blue (Promega Biotec). Two plasmids were obtained from the $\lambda$ NILE- 1 clone and designated pNILE$1 \mathrm{~A}$, with a 2.2 kilobase $(\mathrm{kb}) \mathrm{cDNA}$ insert, and pNILE-1B, with a 0.2 $\mathrm{kb}$ cDNA insert.

Northern blot analysis. For the preparation of total cellular RNA from cloned cell lines, cells were harvested and washed with PBS. The cells were pelleted and resuspended in solution containing $4 \mathrm{~m}$ guanidinium thiocyanate, $0.5 \%$ sodium lauryl sarcosine, $25 \mathrm{~mm}$ sodium citrate $\mathrm{pH}$ 7.0, $2.4 \mathrm{M}$ cesium chloride, and $0.1 \mathrm{M}$ 2-mercaptoethanol. The RNA was pelleted through a solution of $5.7 \mathrm{M}$ cesium chloride in an ultracentrifuge at 33,000 rpm for $16 \mathrm{hr}$ as described by Maniatis et al. (1982). The RNA pellet was dissolved in water and twice precipitated with sodium acetate $(0.1 \mathrm{M})$ and ethanol $(70 \%)$. Poly $(\mathrm{A})^{+}$RNA was isolated by chromatography on oligo-d(T) cellulose (Collaborative Research).

Aliquots of poly (A) ${ }^{+}$RNA $(2.4 \mu \mathrm{g} /$ lane $)$ were prepared in $20 \mathrm{~mm}$ morpholinopropane sulfonic acid, $5 \mathrm{~mm}$ sodium acetate, $1 \mathrm{~mm}$ EDTA $(1 \times$ MOPS), $50 \%$ formamide, and 3\% formaldehyde. The samples were heated to $65^{\circ} \mathrm{C}$, cooled on ice, and supplemented with gel loading buffer (Maniatis et al., 1982). The RNA was fractionated on a horizontal $1 \%$ agarose- $6 \%$ formaldehyde gel and stained with acridine orange to permit visualization of the separated components. After electrophoresis, the gel was soaked for $20 \mathrm{~min}$ in each of 3 solutions: first, $50 \mathrm{~mm} \mathrm{NaOH}$ and $0.1 \mathrm{M} \mathrm{NaCl}$, then $0.1 \mathrm{M}$ Tris $\mathrm{HCl}, \mathrm{pH} 7.5$, and finally $20 \times$ SSPE $(1 \times$ SSPE $=10 \mathrm{~mm}$ sodium phosphate, $150 \mathrm{~mm} \mathrm{NaCl}, 1$ mм EDTA, $\mathrm{pH}$ 7.4). The RNA was transferred overnight to a nitrocellulose sheet (MSI), which was then baked at $70^{\circ} \mathrm{C}$ in a vacuum for $2 \mathrm{hr}$.

The nitrocellulose sheet was prehybridized overnight at $50^{\circ} \mathrm{C}$ in a solution of $5 \times$ SSPE, $50 \%$ formamide, $1 \%$ BSA, $1 \%$ Ficoll, $1 \%$ polyvinylpyrrolidone, and $200 \mathrm{mg} / \mathrm{ml}$ denatured salmon sperm DNA. Hybridization was performed overnight in a fresh solution of the prehybridization solution containing $10^{8} \mathrm{cpm}$ of pNILE-1B, nick-translated with a Boehringer-Mannheim kit. The nitrocellulose sheet was washed 6 times for $30 \mathrm{~min}$ each at $68^{\circ} \mathrm{C}$ in $0.1 \times$ SSPE and $0.1 \%$ SDS. An autoradiogram of the dried sheet was prepared using Kodak XAR-5 film at $-70^{\circ} \mathrm{C}$.

Purification of NILE- $\beta$-galactosidase fusion protein. A lysogen of the NILE-positive clone was produced in $E$. coli $\mathrm{Y} 1089$ (Huynh et al., 1985). A $5 \mathrm{ml}$ overnight culture of the lysogen was added to $500 \mathrm{ml}$ of LB broth and grown for $3 \mathrm{hr}$ at $32^{\circ} \mathrm{C}$ with aeration. At this time, the temperature was raised to $42^{\circ} \mathrm{C}$ by the addition of $500 \mathrm{ml}$ of $1 \% \mathrm{NaCl}$ solution at $70^{\circ} \mathrm{C}$, and growth was allowed to continue for $1 \mathrm{hr}$ at $37^{\circ} \mathrm{C}$ with aeration. Cells were then harvested by centrifugation and lysed by freezing at $-70^{\circ} \mathrm{C}$. The frozen cell pellet was mixed with $10 \mathrm{ml}$ of 50 $\mathrm{mm}$ Tris- $\mathrm{HCl}, 150 \mathrm{~mm} \mathrm{NaCl}$, pH 8.0 (Tris-saline), containing $1 \mathrm{~mm}$ EDTA, $0.3 \mathrm{~mm}$ PMSF, $1 \mathrm{~mm}$ benzamidine, $10 \mu \mathrm{g} / \mathrm{ml}$ soybean trypsin inhibitor, and $10 \mu \mathrm{g} / \mathrm{ml}$ DNase I. Particulate cell debris was removed by centrifugation, and the supernatant was gently shaken overnight at $4^{\circ} \mathrm{C}$ with Sepharose $4 \mathrm{~B}$ beads derivatized with monoclonal antibody against $\beta$-galactosidase. Following the incubation period, the beads were poured into a column and washed thoroughly with Tris-saline. Material bound to the column was eluted with Tris-saline buffer containing $8 \mathrm{M}$ urca. Eluted material was dialyzed extensively against $10 \mathrm{~mm}$ ammonium acetate, pH 7.0, and lyophilized to dryness. SDS-PAGE of this material revealed a major $150 \mathrm{kDa}$ component that was recognized both by rabbit anti- $\beta$-galactosidase (Cappel) and by rabbit anti-L 1 antibody on Western blots (Towbin et al., 1979).

Antisera. Rabbit antiserum against the NILE glycoprotein has been described previously (Stallcup and Beasley, 1985a; Stallcup et al., 1985). Rabbit antibody against L1 glycoprotein was a generous gift from Dr. Melitta Schachner, University of Heidelberg. Monoclonal antibody against $\beta$-galactosidase was provided by Dr. Larry Rohrschneider, Hutchinson Cancer Center. Rabbit antibody against the NILE- $\beta$-galactosidase fusion protein was produced by an initial subcutaneous injection of the purified fusion protein in complete Freund's adjuvant. Two booster immunizations were given on days 14 and 24 with fusion protein emulsificd in incomplete Freund's adjuvant. Bleeds were taken on days 20,34 , and 37 . A preimmune bleed from the same rabbit was used as a control in the immunoprecipitation experiments.

Immunofluorescence. Cultures of postnatal day 6 rat cerebellum were prepared as described previously (Stallcup et al., 1983) and used to test the immunoreactivity of rabbit antibody against the NILE- $\beta$-galactosidase fusion protein. Some cultures were fixed prior to staining by treatment for $1 \mathrm{hr}$ at $4^{\circ} \mathrm{C}$ with $1 \%$ paraformaldehyde in $0.1 \mathrm{M}$ phosphate buffer, $\mathrm{pH}$ 7.4. In these experiments $0.1 \%$ Triton $\mathrm{X}-100$ was added to the primary antibody to allow permeabilization of the cells. Other cultures were used without fixation and permeabilization so that only cellsurface components were accessible to the antibody. Serum from the preimmune bleed was used as a control in these experiments. Fluorescein-labeled goat antibody against rabbit immunoglobulin (Tago) was used as a second antibody. Incubations with both the primary and secondary antibodies were of $30 \mathrm{~min}$ durations and were followed by 4 washes with HEPES-buffered DMEM containing $2 \%$ fetal calf serum. The preparations were coverslipped in glycerol containing $0.1 \mathrm{M}$ Tris $\mathrm{HCl}, \mathrm{pH} 8.5$, and viewed under epifluorescence with a Nikon Optiphot microscope. Photographs were taken using Kodak Tri-X 400 film.

Radioisotopic labeling and immune precipitation. Cell-surface labeling with ${ }^{125}$ I (Amersham) was carried out using the lactoperoxidase method (Hubbard and Cohn, 1972). Metabolic phosphorylation was achieved by growing cells overnight in phosphate-free DMEM containing 200 $\mu \mathrm{C} / \mathrm{ml}$ dipotassium ${ }^{32} \mathrm{P}$-phosphate (New England Nuclear).

Labeled cells were washed 3 times with PBS and extracted with $1 \%$ Nonidet P40 (NP40) in PBS. Insoluble material was removed by centrifugation. The supernatants were precleared by incubation with Protein A-Sepharose (Sigma) and then used for immune precipitation. Extracts were incubated with the appropriate rabbit antiserum for $2 \mathrm{hr}$ and then treated with Protein A-Sepharose for an additional $2 \mathrm{hr}$ to isolate immune complexes. The Protein A-Sepharose-immunoglobulin complexes were washed 3 times with PBS containing $0.02 \%$ SDS and $0.1 \%$ NP40 and boiled in electrophoresis sample buffer (containing 3\% SDS and 5\% 2-mercaptoethanol) to solubilize the sample.

$P A G E$ and autoradiography. Gradient gels containing 2-20\% polyacrylamide were used to analyze most of the immune precipitates. In a few cases, $6 \%$ gels were used. The Laemmli (1970) discontinuous buffer system was used in both cases. Stained gels were dried under vacuum, and autoradiograms were prepared using Kodak XAR-5 film and Cronex intensifying screens.

$D N A$ sequencing. Sequence analysis by the dideoxynucleotide method was performed using a Promega Biotec K/RT kit and dATP $\left(\alpha^{35}\right.$ S) from New England Nuclear. Reaction products were analyzed by electrophoresis in a BioRad Geneseq apparatus, followed by autoradiography with Kodak XAR-5 film.

\section{Results}

\section{Identification of NILE $M R N A$ and partial sequence of the encoded polypeptide}

We used rabbit antibody against $L 1$ to select a NILE-positive clone ( $\lambda$ NILE-1) from a $\lambda$ gt 11 expression library prepared using mRNA from PC1 2 cells. The $2.4 \mathrm{~kb} \lambda$ NILE- 1 cDNA insert was subcloned into plasmids as 2 Eco RI fragments-the $2.2 \mathrm{~kb}$ pNILE-1A and the $0.2 \mathrm{~kb}$ pNILE-1B. The pNILE-1B subclone was used as a probe for Northern blot analysis of NILE mRNA species present in several neural cell lines that had previously been characterized for the presence or absence of NILE (Stallcup et al., 1983). Figure 1 shows that the probe does not recognize any mRNA components from 2 NILE-negative cell lines, B9 and $B 92$. In contrast, hybridizing messages of about 2.0 and 6.8 $\mathrm{kb}$ are seen in the poly $(\mathrm{A})^{+}$RNA from 2 NILE-positive cell lines, $\mathrm{PC} 12$ and $\mathrm{B} 35$.

The nucleotide sequence of the pNILE-1B clone is shown in Figure 2 along with the amino acid sequence deduced from the only open reading frame in this segment of cDN $\Lambda$. The corresponding sequences for the $\mathrm{Ll}$ glycoprotein (Moos et al., 1988) are shown for comparison. The 2 sequences differ in only 11 nucleotides and 2 amino acids.

\section{Recognition of NILE by antibody against putative NILE- $\beta$ - galactosidase fusion protein}

On Western blots, a $150 \mathrm{kDa}$ polypeptide from the $\lambda$ NILE- 1 clone was recognized by both anti-L1 and anti- $\beta$-galactosidase 


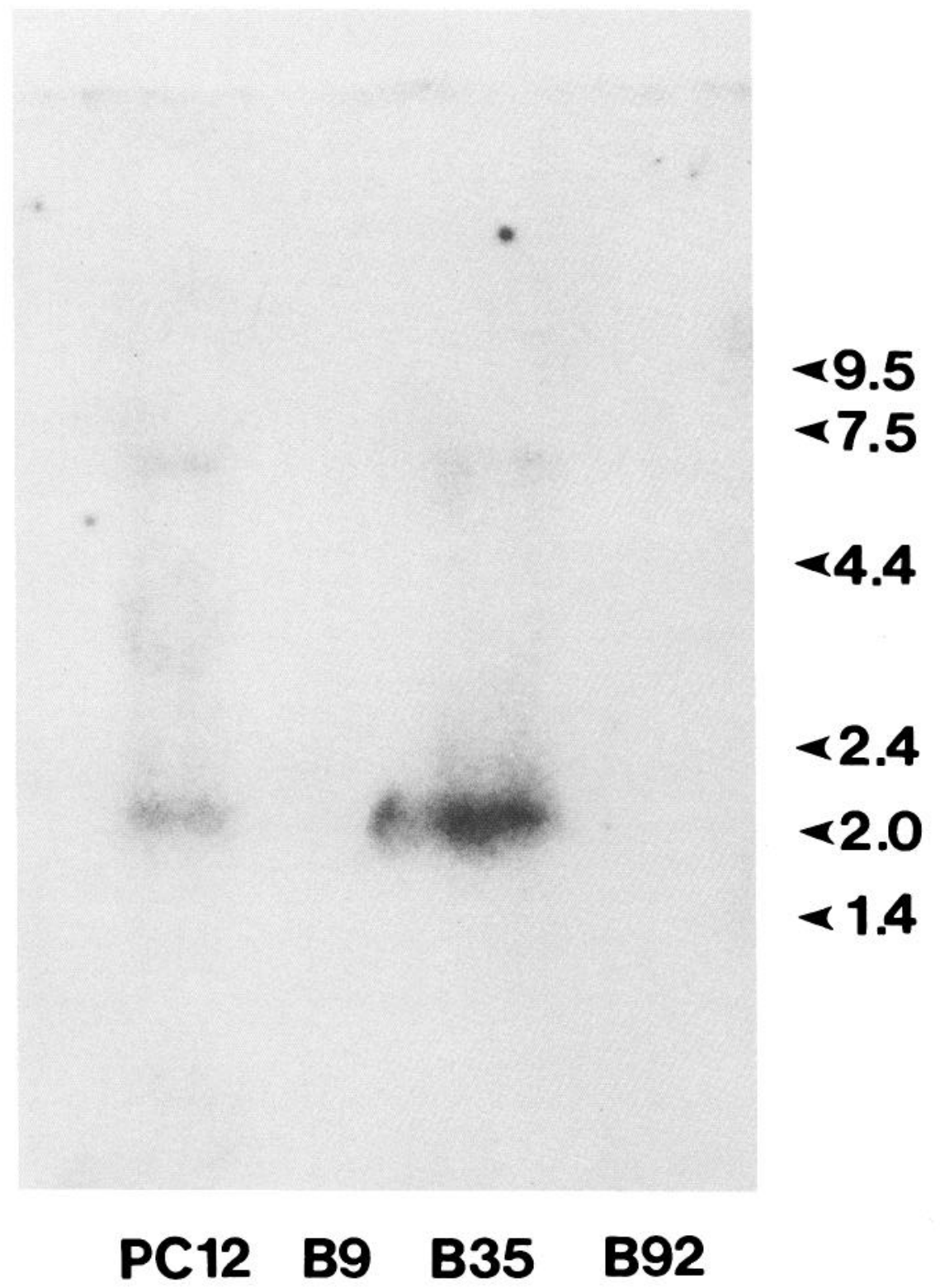

Figure 1. Northern blot analysis of NILE mRNA. Poly (A) ${ }^{+}$RNA, $2.4 \mu \mathrm{g}$ from each of several neural cell lines, was fractionated on a $1 \%$ agaroseformaldehyde gel and transferred to nitrocellulose. The Northern blot was probed with the pNILE-1B cDNA as described in Materials and Methods. The 2 neuronal cell lines PC12 and B35 have hybridizing species of about 2.0 and $6.8 \mathrm{~kb}$, while the 2 non-neuronal cell lines lack hybridizing components. The sizes of RNA standards are given on the right-hand side in kilobases. antibodies. This putative NILE- $\beta$-galactosidase fusion protein was purified by immunoaffinity chromatography on anti- $\beta$-galactosidase-Sepharose $4 \mathrm{~B}$ and used to immunize a rabbit.

We assessed the reactivity of the anti-fusion protein antibody (anti-NILE- $\beta$-gal) in a series of immune precipitation experiments. Three neuronal cell lines-PC12 (rat), B35 (rat), and $\mathrm{C} 1300 \mathrm{cl}$. N18 (mouse)-were used as the primary sources of NILE for this analysis, and the results reported here were confirmed with each of the 3 cell lines. The figures do not show the data for all 3 cell lines in every case, but instead provide selected examples of the results with the different cell lines to illustrate the generality of the findings. A human neuroblastoma, IMR32 , was used in a few cases. The cell lines were labeled with ${ }^{125} \mathrm{I}$ and extracted with NP40, and the extracts were treated with anti-NILE- $\beta$-gal. Parallel samples were treated with preimmune serum and with rabbit anti-NILE antibodies. Figure 3 shows that preimmune serum does not recognize ${ }^{125}$ I-labeled components in these extracts, but that the anti-NILE and anti-NILE$\beta$-gal antibodies both recognize identical NILE species from each of the 3 cell lines shown. The relative effectiveness of the 2 antisera in recognizing the various forms of NILE is reproducible. They are approximately equal in their ability to immunoprecipitate PC12 NILE, but anti-NILE is more effective with B35 NILE, while anti-NILE- $\beta$-gal is more effective with N18 NILE. This suggests that there may be differences in the structure of NILE from the different cell lines. In the case of the human cell line IMR-32, anti-NILE- $\beta$-gal recognizes a NILElike molecule of $200 \mathrm{kDa}$ that is not recognized by anti-NILE (not shown). Thus, anti-NILE- $\beta$-gal may recognize an epitope that is more highly conserved across species than the epitopes recognized by anti-NILE.

The difference in molecular weights of the NILE molecules from these different cell types has already been noted (Stallcup et al., 1983; Stallcup and Beasley, 1985b). The fact that the component recognized by anti-NILE- $\beta$-gal varies in size in exactly the same way as the component recognized by anti-NILE reinforces the conclusion that anti-NILE- $\beta$-gal does, in fact, react with NILE. Further verification of this is provided in 
Figure 2. Partial cDNA sequence and deduced amino acid sequence of NILE. A comparison is made between the sequence obtained from the pNILE-1B cDNA and the sequence of the cytoplasmic portion of the $\mathrm{Ll}$ glycoprotein (Moos et al., 1988). Asterisks mark the termination codon in L1; boxes identify residues that are nonidentical in the 2 sequences. lys arg ser lys gly gly lys tyr ser val lys asp lys lys glu asp thr gln AAA CGC AGC AAG GGT GGC AAA TAC TCA GTG AAG GAC AAG AAG GAG GAC ACT GAG $--G$ GAG GAC ACT GAG --- glu asp thr gln

val asp ser glu ala arg pro met lys asp glu thr phe gly glu tyr arg ser GTA GAT TCC GAG GCC CGG CCC ATG AAA GAC GAG ACC TTC GGC GAG TAC AGG TCC GTA GAT TCC GAG GCC CGG CCC ATG AAA GAC GAG ACC TTC GGC GAG TAC AGG TCC val asp ser glu ala arg pro met lys asp glu thr phe gly glu tyr arg ser

leu glu ser asp asn glu glu lys ala phe gly ser ser gln pro ser leu asn CTG GAG AGT GAC AAT GAA GAG AAG GCC TTा GGC AGC AGC CAG CCA TCT CTC AAC] CTG GAG AGT GAC AAT GAA GAG AAG GCC TIC GGC AGC AGC CAG CCA TCT CTC AAT leu glu ser asp asn glu glu lys ala phe gly ser ser gln pro ser leu asn

gly asp ile lys pro leu gly ser asp asp ser leu ala asp tyr gly gly ser GGA GAC ATC AAA CCC CTA CGC AGT GAT GAC AG CTG GCT GAT TAT GGG GGC AGT GGA GGC ATC AAA CCC CTA GGC AGT GAT GAC AGD CTG GCT GAT TAT GGG GGC AGT gly gly ile lys pro leu gly ser asp asp ser leu ala asp tyr gly gly ser

val asp val gln phe asn glu asp gly ser phe ile gly gln tyr ser gly lys GTG GA GTC CAG TTC AAT GAG GAT GGC TCT TTC ATC GGC CAG TAC AGT GGC AAG GTG GAJ GTC CAG TTC AAT GAG GAT GGC TCT TTC ATC GGC CAD TAC AGT GGC AAD val asp val gln phe asn glu asp gly ser phe ile gly gln tyr ser gly lys

lys gाu lys glu ala ala gly gly asn asp ser ser gly ala thr ser pro ile AAA GAG AAG GAG GCA GCA GGA GGC AAT GAC AGT TCA GGG GCT ACC TCT CCT ATC AAA AAA AA A $A$ A-

lys lys lys ---
Figure 7. Neuraminidase treatment and trypsin treatment of B 35 cells produce anti-NILE-reactive species that migrate more rapidly than intact NILE. In each case, anti-NILE- $\beta$-gal recognizes components indistinguishable from those recognized by anti-NILE.

\section{Location of the epitope recognized by anti-NILE- $\beta$-gal}

Faissner et al. (1985) have shown that the $200 \mathrm{kDa}$ L1 molecule can be cleaved by mild trypsin treatment into fragments of 80 and $140 \mathrm{kDa}$, neither of which is released from the cell by the trypsinization procedure. After treatment of ${ }^{125} \mathrm{I}$-labeled PC12 cells with $10 \mu \mathrm{g} / \mathrm{ml}$ trypsin for $15 \mathrm{~min}$ at room temperature and subsequent NP40 extraction of the trypsinized cells, we can show that anti-NILE- $\beta$-gal immunoprecipitates both a 160 and an $85 \mathrm{kDa}$ component (Fig. $4 A$ ). The $85 \mathrm{kDa}$ component is phosphorylated, while the $160 \mathrm{kDa}$ component is not (data not shown), suggesting that these 2 fragments from the $230 \mathrm{kDa}$ NILE molecule correspond to the 80 and $140 \mathrm{kDa}$ fragments
Figure 3. Recognition of NILE by anti-NILE- $\beta$-gal and anti-NILE. Three neuronal cell lines (PC12, B35, and N18) were labeled with ${ }^{125} I$ and extracted with NP40 as described in Materials and Methods. Aliquots containing equal numbers of cpm were subjected to immune precipitation using 3 different sera: anti-NILE $(N)$, preimmune serum $(P)$, and anti-NILE- $\beta$-gal fusion protein $(F)$. The immunoprecipitates were analyzed by SDS-PAGE using a $2-20 \%$ gradient gel. Note that, although the NILE species from the 3 cell lines vary in apparent molecular weight, the antiNILE and anti-NILE- $\beta$-gal reagents recognize the same component in each case. The preimmune serum is negative in each case.

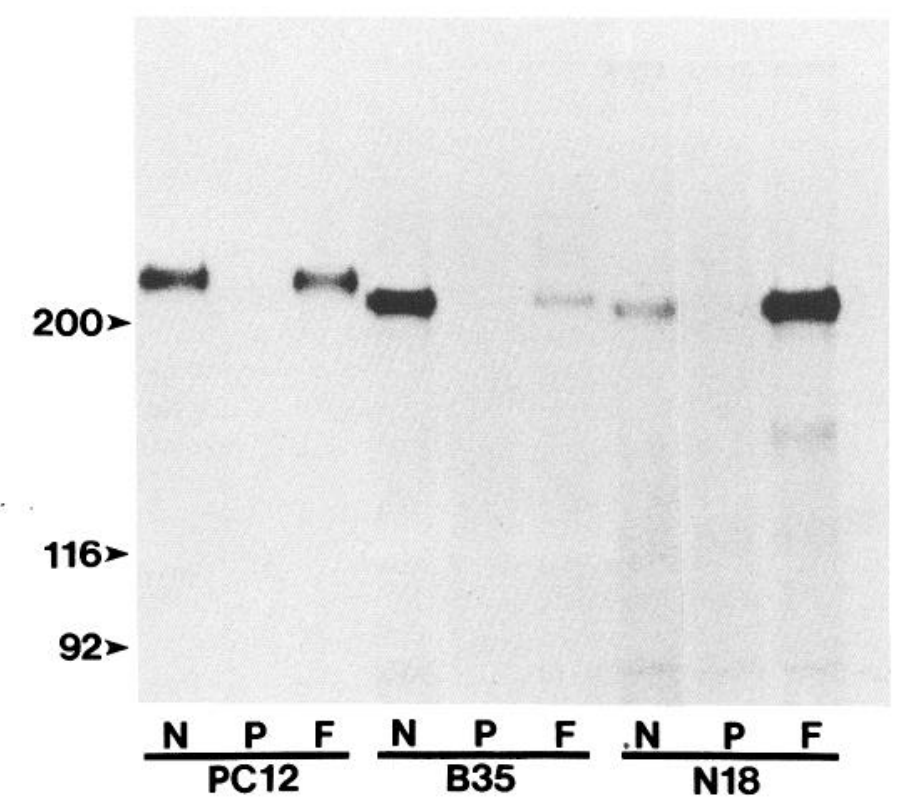



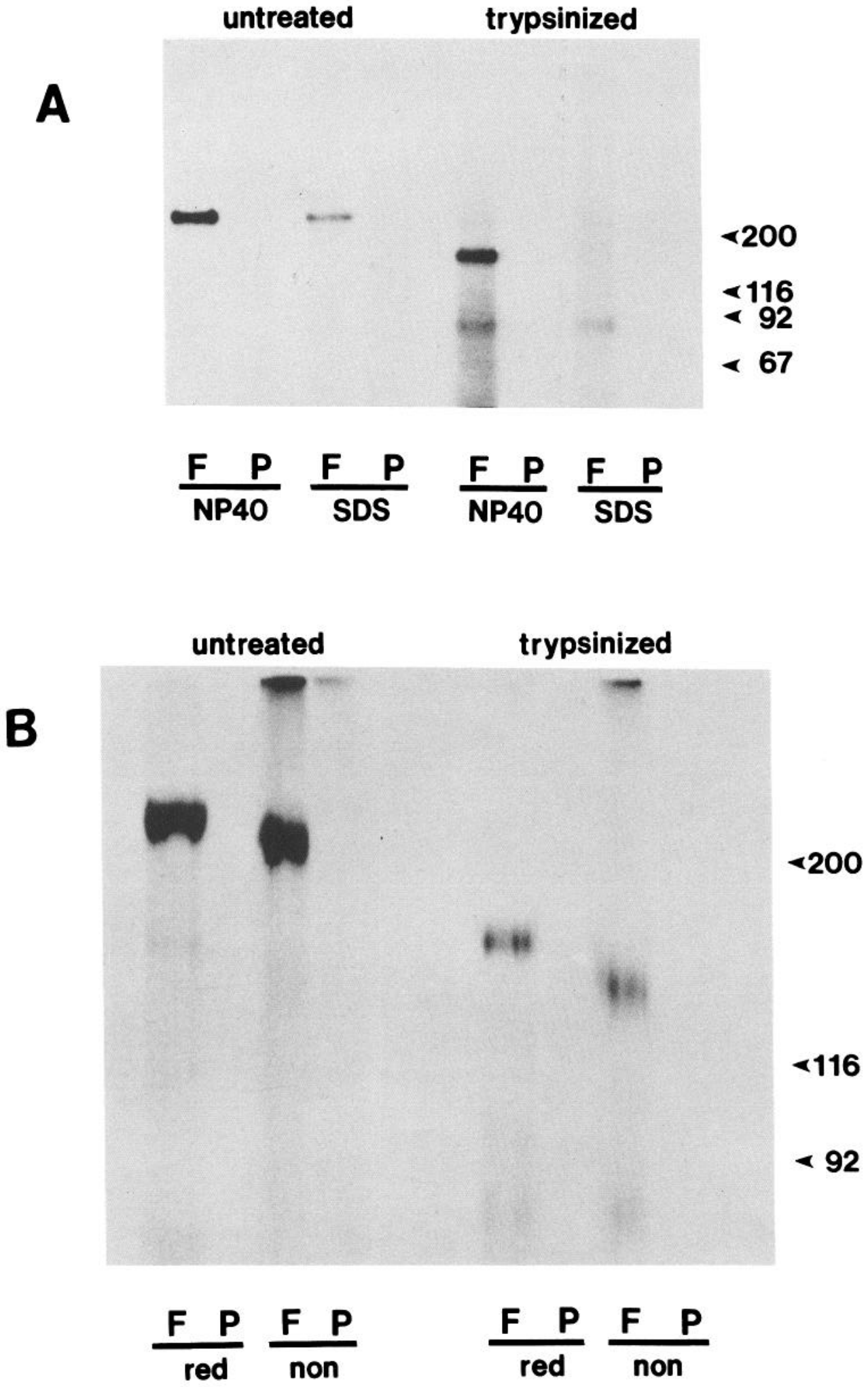

Figure 4. Intrachain interactions within NILE. $A$, Noncovalent interactions. ${ }^{125} \mathrm{I}$-labeled $\mathrm{PC} 12$ cells were left untreated or treated with $10 \mu \mathrm{g} / \mathrm{ml}$ trypsin for $15 \mathrm{~min}$ at room temperature. Extracts of both samples were made with $1 \%$ NP40. Half of each sample received no other detergent treatment, while the other half was boiled with $0.2 \%$ SDS. The various extracts were then incubated with $10 \mu \mathrm{l}$ of antibody against the NILE- $\beta$-gal fusion protein $(F)$ or with $10 \mu l$ of preimmune serum $(P)$. Protein A-Sepharose was used to complete the immune precipitation, and immune precipitates were analyzed on $2-20 \%$ SDS-polyacrylamide gradient gels. Anti-NILE- $\beta$-gal recognizes intact NILE $(230 \mathrm{kDa})$ before and after treatment with SDS. AntiNILE- $\beta$-gal immunoprecipitates both the 160 and $85 \mathrm{kDa}$ tryptic fragments of NILE prior to treatment with SDS but recognizes only the $85 \mathrm{kDa}$ fragment after SDS treatment. $B$, Disulfide bonding. ${ }^{225}$ I-labeled $\mathrm{PC} 12$ cells were left untreated or treated with $10 \mu \mathrm{g} / \mathrm{ml}$ trypsin for $15 \mathrm{~min}$ at room temperature. Extracts of both samples were made with $1 \%$ NP40, and immunoprecipitates were prepared using $10 \mu \mathrm{l}$ of antibody against NILE- $\beta$-gal fusion protein $(F)$ or $10 \mu$ lof preimmune serum $(P)$. Immune precipitates were dissolved by boiling in nonreducing (non) electrophoresis sample buffer or in reducing (red) sample buffer containing $5 \%$ 2-mercaptoethanol. Electrophoretic analysis was made on $6 \%$ SDSpolyacrylamide gels. The 160 and 85 $\mathrm{kDa}$ tryptic fragments are not linked by disulfide bonds, since they migrate separately under both reducing and nonreducing conditions. However, the 160 $\mathrm{kDa}$ fragment appears to contain disulfide bonds that cause the fragment to migrate as a more compact entity under nonreducing conditions. A similar effect is seen with the intact NILE molecule. of L1 (see Faissner et al., 1985; Sadoul et al., 1988). In the absence of detergent there is very little release of either fragment from PC12 cells during the trypsinization period (see below for a discussion of longer time periods).

Since the limited amount of NILE polypeptide present in the NILE- $\beta$-galactosidase fusion protein makes it extremely un- likely that anti-NILE- $\beta$-gal could recognize determinants on both ends of the NILE molecule, the ability of the antibody to immunoprecipitate both fragments is puzzling. This behavior can be explained, however, if the 2 fragments still associate tightly after proteolytic clipping. One means of maintaining such an association is disulfide bonding between the 2 fragments. If this 


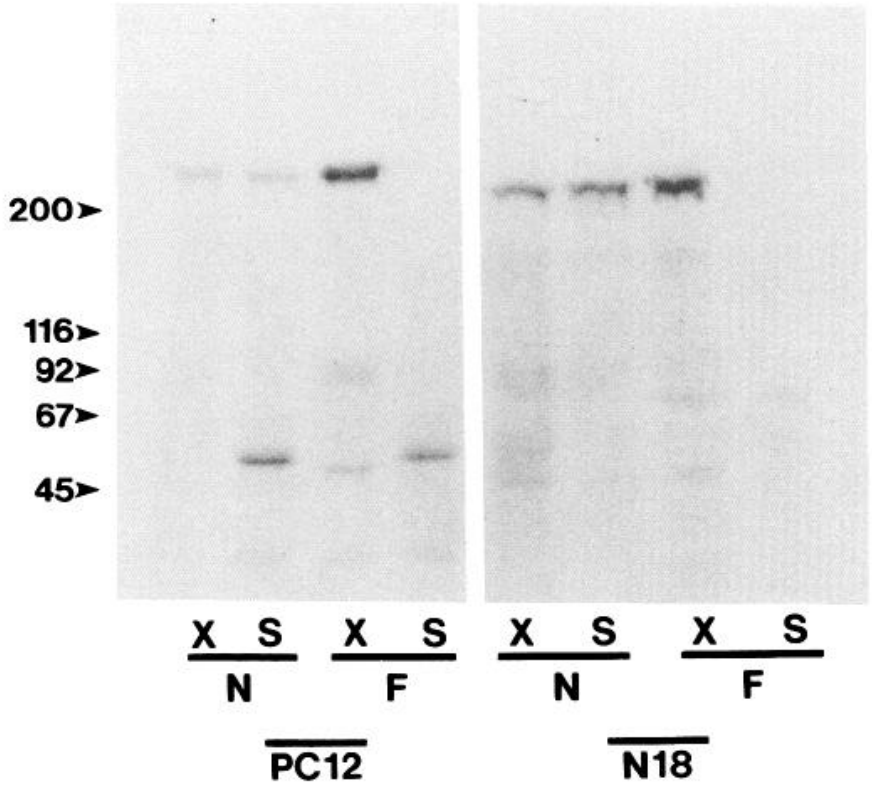

Figure 5. Exposure of NILE determinants on the cell surface. PC12 cells and N18 cells were labeled with ${ }^{125}$ I. One aliquot of each cell line was extracted with NP40 $(X)$ and the extract used for immune precipitation with anti-NILE $(N)$ and anti-NILE- $\beta$-gal $(F)$. Other aliquots of each cell line were treated with the same 2 antibodies prior to extraction with NP40, so that only determinants exposed on the cell surface $(S)$ could be recognized. After a $1 \mathrm{hr}$ incubation with antibodies, these cells were washed 3 times with PBS to remove unbound antibody. NP40 extracts were then prepared and treated with Protein A-Sepharose to isolate the immune precipitates. Precipitates were analyzed on a 2-20\% gradient gel. Whereas anti-NILE recognizes NILE both in the detergent extracts and exposed on the surface of intact cells, anti-NILE- $\beta$-gal does not recognize NILE determinants exposed on the cell surface. The determinant recognized by this antibody is exposed only after detergent extraction.

is the case, electrophoresis of trypsin-treated NILE under nonreducing conditions should reveal a species with a mobility similar to that of the intact NILE molecule. Figure $4 B$ shows that this is not the case. Typsinized NILE under nonreducing conditions still migrates as 2 nonlinked fragments. The fact that the larger of the 2 fragments migrates more rapidly under nonreducing conditions than under reducing conditions strongly suggests, however, that disulfide bonding plays a role in stabilizing the conformation of this portion of the molecule. Nonreducing conditions also produce a shift in mobility of the intact NILE molecule.

Apparently, noncovalent forces are responsible for the tight association of the 2 NILE fragments (Sadoul et al., 1988). If the NP40 extracts of ${ }^{125}$ I-labeled, trypsinized PC12 cells are boiled with $0.2 \%$ SDS prior to immune precipitation, these noncovalent interactions are disrupted and only the $85 \mathrm{kDa}$ fragment is immunoprecipitated by anti-NILE- $\beta$-gal (Fig. $4 A$ ). A control experiment shows that the intact $230 \mathrm{kDa}$ NILE molecule is recognized by anti-NILE- $\beta$-gal after the SDS treatment.

In the foregoing experiments, the cells were always extracted with detergent prior to the addition of antibodies. In another set of experiments, intact ${ }^{125} \mathrm{I}$-labeled cells were treated with anti-NILE and anti-NILE- $\beta$-gal for $1 \mathrm{hr}$ and then washed free of unbound antibody before being extracted with NP40. In this way only determinants exposed on the cell surface could be recognized by the antibodies. Figure 5 shows that although both antibody preparations recognize NILE after it has been extracted from PC12 and N18 cells, only anti-NILE is able to recognize NILE exposed on the surface of intact cells. The epitope recognized by anti-NILE- $\beta$-gal is apparently not exposed on the cell surface. This result is supported by immunofluorescence experiments with anti-NILE- $\beta$-gal (Fig. 6). The antibody does not stain living cerebellar neurons in culture, showing that the epitope recognized by the antibody is not exposed on the cell surface ( $a$ and $b$ ). However, if the cultures are fixed and permeabilized to allow access to intracellular structures, the antiNILE- $\beta$-gal antibody stains both the cell bodies and processes of neurons ( $c$ and $d$ ). Preimmune serum also stains neuronal cell bodies in the fixed, permeabilized cultures ( $e$ and $f$ ), suggesting that this portion of the labeling is nonspecific or at least irrelevant to the NILE- $\beta$-galactosidase epitope. Thus, the epitope recognized by the anti-NILE- $\beta$-gal antibody is an intracellular one and is localized to neurites. The preferential staining of neuronal processes, as opposed to cell bodies, has been reported to be characteristic of anti-NILE antibodies (Stallcup et al., 1983, 1985; Stallcup and Beasley, 1985a).

It has been noted previously that a slightly truncated form of the NILE molecule is slowly released or secreted over a period of hours from the surface of neuronal cells even in the absence of detergent (Salton et al., 1983b; Sweadner, 1983; RichterLandsberg et al., 1984; Stallcup and Beasley, 1985b). The mechanism of the spontaneous release is not well understood, but it is most often attributed to proteolytic clipping of the molecule (Sweadner, 1983; Richter-Landsberg et al., 1984; Stallcup and Beasley, 1985b). Figure 7 compares the secreted and detergentextracted forms of NILE derived from control B35 cells, neuraminidase-treated B35 cells, and trypsin-treated B35 cells. It is apparent that anti-NILE- $\beta$-gal does not recognize the secreted form of NILE. This same phenomenon is observed in the case of PC12 and N18 cells (data not shown). Thus, secreted NILE must lack a determinant that is present on the extracted form of NILE. It seems likely that the determinant in question is located in the $15 \mathrm{kDa}$ of material that is missing from released NILE. Two experiments indicate that this $15 \mathrm{kDa}$ is lost from the phosphorylated domain of the molecule. First, the truncated, secreted form of NILE immunoprecipitated by anti-NILE is not labeled with ${ }^{32} \mathrm{P}$, indicating that the phosphorylated portion of the molecule (like the anti-NILE- $\beta$-gal determinant) is lost during the release process (data not shown). Second, the $160 \mathrm{kDa}$ tryptic fragment found in the secreted material is indistinguishable from its detergent-extracted counterpart, suggesting that this domain of the molecule is unaffected by secretion and that the proteolytic event must occur in the $85 \mathrm{kDa}$ domain (Fig. 7).

\section{Discussion}

The cDNA clone $\lambda$ NILE- 1 was selected from a $\lambda g t 11$ library on the basis of its reactivity with antibody against the L1 glycoprotein. $\lambda$ NILE- 1 has a cDNA insert of $2.4 \mathrm{~kb}$ that was subcloned into plasmids in the form of 2 distinct Eco RI fragments. The smaller of the 2 subclones, pNILE-1B with a $0.2 \mathrm{~kb}$ cDNA insert, was used as a probe to identify mRNA for NILE. The sources of RNA for these experiments were 4 cloned neural cell lines that had previously been tested for expression of NILE glycoprotein (Stallcup et al., 1983). The 2 non-neuronal, NILEnegative cell lines (B9 and B92) did not have RNA species capable of hybridizing with the pNILE-1B probe, while the 2 neuronal, NILE-positive cell lines (B35 and PC12) each had RNA components of about 2.0 and $6.8 \mathrm{~kb}$ that hybridized with 

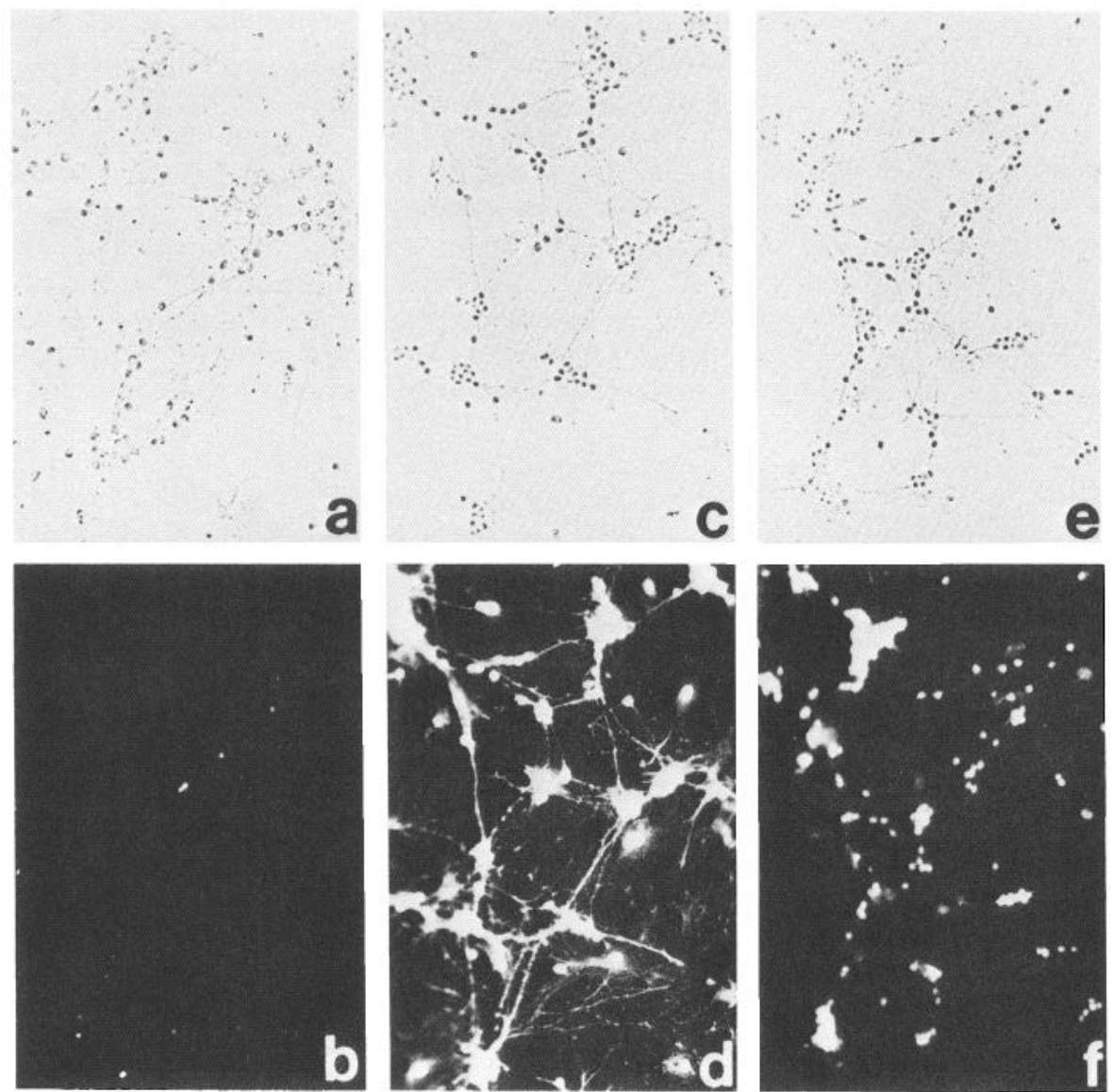

Figure 6. Immunofluorescent staining with anti-NILE- $\beta$-gal. Primary cultures of postnatal day 6 cerebellum were stained with anti-NILE- $\beta$-gal and fluorescein-labeled goat anti-rabbit immunoglobulin as follows: $a$ and $b$, Living cultures were treated with a $1 / 100$ dilution of anti-NILE- $\beta$-gal. No staining was observed under these conditions. $c$ and $d$, Cultures fixed with $1 \%$ paraformaldehyde were treated with a $1 / 100$ dilution of anti-NILE- $\beta$-gal containing $0.1 \%$ Triton $X-100$. Staining of both neuronal cell bodies and processes was observed. $e$ and $f$, Cultures fixed with $1 \%$ paraformaldehyde were treated with a $1 / 100$ dilution of preimmune serum containing $0.1 \%$ Triton $\mathrm{X}-100$. Staining of neuronal cell bodies, but not of processes, was observed.

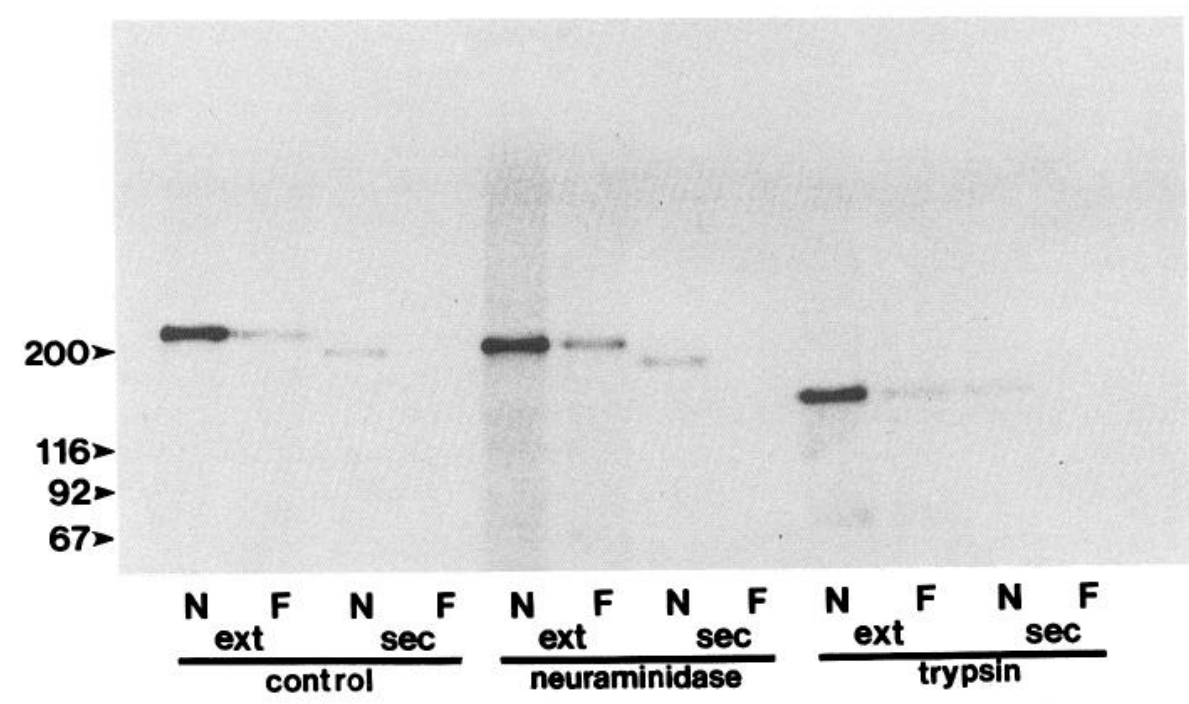

Figure 7. Secretion of NILE and NILE fragments. B35 cells were labeled with ${ }^{125}$ I and were either left untreated (control), treated with neuraminidase $\left(0.02 \mathrm{U}\right.$ for $1 \mathrm{hr}$ at $\left.37^{\circ} \mathrm{C}\right)$, or treated with trypsin $(10 \mu \mathrm{g} / \mathrm{ml}$ for $15 \mathrm{~min}$ at room temperature). One aliquot of each of these $3 \mathrm{groups}$ of cells was extracted with NP40 (ext) and subjected to immune precipitation with anti-NILE $(N)$ and anti-NILE- $\beta$-gal $(F)$. A second aliquot of each group was allowed to "secrete" material into the medium for $4 \mathrm{hr}(\mathrm{sec})$. Cells were removed from this medium by centrifugation, NP40 was added to the supernatant to a final concentration of $1 \%$, and immunoprecipitates were prepared with anti-NILE and anti-NILE- $\beta$-gal. Immune precipitates were analyzed on a $2-20 \%$ gradient gel. With extracted material, anti-NILE and anti-NILE- $\beta$-gal immunoprecipitate identical components in each of the 3 preparations: a $215 \mathrm{kDa}$ molecule from control cells, a $205 \mathrm{kDa}$ component from neuraminidase-treated cells, and a $160 \mathrm{kDa}$ component from trypsinized cells. The secreted form of NILE is not recognized by anti-NILE- $\beta$-gal in any of the 3 cases. Note that the secreted NILE is smaller than extracted NILE in the case of control and neuraminidase-treated cells but is indistinguishable from extracted NILE in the case of trypsintreated cells. 


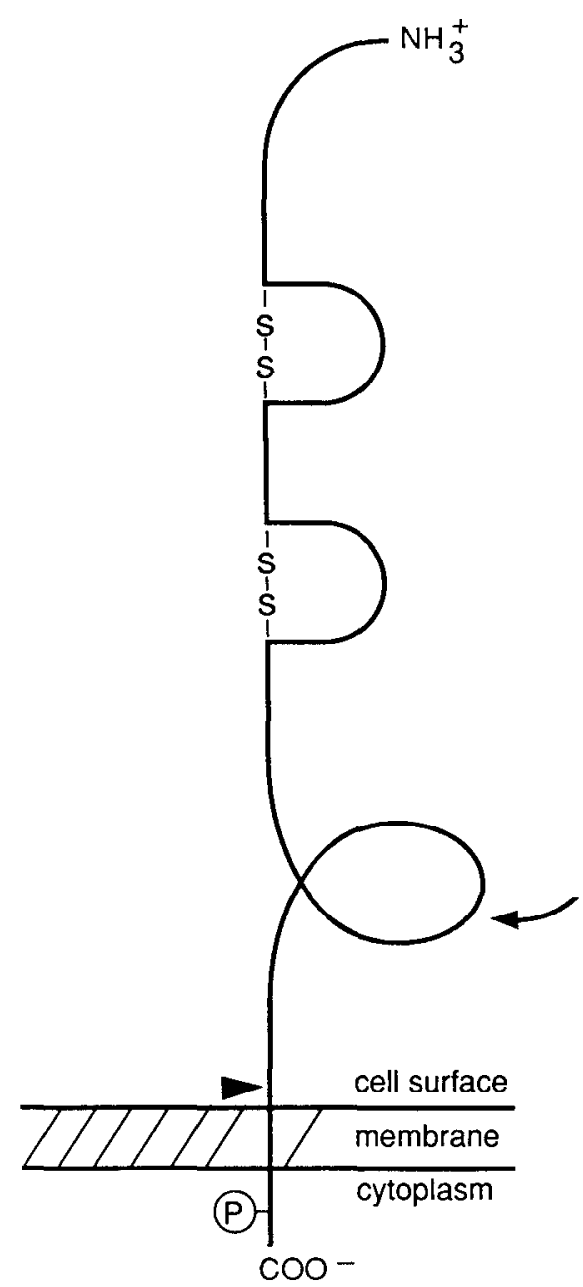

Figure 8. Membrane topography of NILE. Features of the NILE molecule are depicted as follows: $\mathrm{NH}_{3}{ }^{+}$, amino terminus; $\mathrm{COO}^{-}$, carboxy terminus; S-S, intrachain disulfide bond; $\$$, site of trypsin cleavage; site of proteolysis leading to release of soluble NILE;(尺), site(s) of phosphorylation. The epitope recognized by the anti-NILE- $\beta$-gal antibody is located in the cytoplasmic portion of the molecule near the carboxy terminus.

the probe. The nonglycosylated NILE polypeptide from $\mathrm{PC} 12$ cells has been estimated by SDS-P $\Lambda$ GE to have a molecular size of $160 \mathrm{kDa}$ (Stallcup and Beasley, 1985b) and could thus be encoded by a message of roughly $3.7 \mathrm{~kb}$. The $6.8 \mathrm{~kb}$ species seen on the Northern blot therefore appears to be large enough to code for NILE, while the $2.0 \mathrm{~kb}$ component is too small for this purpose.

Tacke et al. (1987) have reported isolation of 2 cDNA clones for the L1 molecule, which is thought to be the mouse equivalent of NILE (Bock et al., 1985; Sajovic et al., 1986). One of these clones was shown to hybridize with an mRNA species of about $6 \mathrm{~kb}$ that is present specifically in nervous tissue. It seems highly probable that the $6.8 \mathrm{~kb}$ species seen in our experiments corresponds to the $6 \mathrm{~kb}$ species identified in the $\mathrm{L} 1$ experiments. Sajovic et al. (1987) have reported hybridization of NILE cDNA clones with PC12 mRNA species of $1.9,2.4,3.4$, and $5.9 \mathrm{~kb}$. It seems possible that the smallest and largest of these species might correspond to our 2.0 and $6.8 \mathrm{~kb}$ components. We did not detect hybridizing species of intermediate sizes.

A clue to the nature of the $2.0 \mathrm{~kb}$ RNA species may be provided by Northern blot analysis using the $2.2 \mathrm{~kb}$ pNILE-1A subclone as a probe. In this experiment a hybridizing component of $2.0 \mathrm{~kb}$ is seen in the $\mathrm{B} 35$ and $\mathrm{PC} 12$ cell lines but not in the $\mathrm{B} 9$ and $\mathrm{B} 92$ cell lines (not shown). No hybridization is seen with the $6.8 \mathrm{~kb}$ spccies, suggesting that the $2.0 \mathrm{~kb}$ RNA and pNILE$1 \mathrm{~A}$ itself are unrelated to NILE and that the juxtaposition of pNILE- $1 \mathrm{~A}$ and $\mathrm{pNILE-1B}$ in the $\lambda$ NILE- 1 clone is the result of duplicate ligation. In support of this, sequence analysis of pNILE1 A reveals an $88 \%$ identity with rat mitochondrial cytochrome oxidase. pNILE-1A cDNA contains several adenosine-rich stretches, and we suspect that hybridization of pNILE-1B with the putative $2.0 \mathrm{~kb}$ cylochrome oxidase mRNA may occur via the stretch of 14 consecutive adenosines near the $3^{\prime}$ end of the clone (Fig. 2).

The sequence data presented in Figure 2 indicate that pNILE$1 \mathrm{~B}$ contains an open reading frame spanning the 240 base length of the clone. Comparison of this partial nucleotide sequence with that of Moos et al. (1988) reveals that NILE-1B overlaps with a substantial portion of the Ll message coding for the cytoplasmic domain. Neither the transmembrane region nor the carboxy terminus are represented in the pNILE-1B subclone. The extent of the identity between this region of NILE and L1 is striking. The 2 sequences differ by only 2 amino acids out of 79.

Western blot analysis of the proteins produced by the $\lambda$ NILE- 1 clone identifies a $150 \mathrm{kDa}$ component recognized both by antibody against $\beta$-galactosidase and by antibody against $L 1$, strongly indicating that the clone does indeed produce a NILE$\beta$-galactosidase fusion protein. To demonstrate conclusively that the fusion protein contains an authentic NILE sequence, we purified the protein and raised a rabbit antibody against it. Immunoprecipitation experiments establish the fact that this antibody (anti-NILE- $\beta$-gal) recognizes authentic NILE from neuronal cell lines. The identification of the immunoprecipitated component as NILE is based on our finding that, in comparing 3 different neuronal cell lines, the anti-NILE- $\beta$-gal antibody recognizes 3 different-sized species of NILE. Anti-NILE antibody recognizes these same 3 species. Moreover, the antiNILE- $\beta$-gal antibody recognizes partially degraded forms of NILE produced by neuraminidase and trypsin treatment. These observations, in tandem with the Northern blot analysis and the sequence data, show that the $\lambda$ NILE- 1 cDNA clone is authentic and contains a sequence coding for a portion of the NILE polypeptide.

In previous work, we have considered the possibility that NILE molecules from different cell types may differ not only at the level of glycosylation, but also in their polypeptide structure. In support of this idea, we showed that deglycosylated NILE core polypeptides from different cell lines were distinguishable in mobility on SDS-PAGE (Stallcup and Beasley, 1985b). In the present work, we have observed that the anti-NILE and antiNILE- $\beta$-gal antibodies differ in their quantitative ability to immunoprecipitate NILE from different cell lines. Anti-NILE is more effective in immunoprecipitating NILE from B35 cells, while anti-NILE- $\beta$-gal is more effective with NILE from C1300 cl. N18 cells. This suggests that there are differences in the antigenic determinants present on the various NILE polpeptides.

The reactivity of the anti-NILE- $\beta$-gal antibody also gives some insight into the structure of NILE and its presentation on the cell surface. Our experiments identify 2 fragments of NILE produced by mild trypsinization: a nonphosphorylated $160 \mathrm{kDa}$ component and a phosphorylated $85 \mathrm{kDa}$ component. These correspond to the 140 and $80 \mathrm{kDa}$ fragments produced by mild 
trypsinization of the smaller L1 glycoprotein (Faissner et al., 1985). As shown by Sadoul et al. (1988), in NP40 extracts the 2 fragments do not dissociate from each other, and thus both are immunoprecipitated by anti-NILE- $\beta$-gal. The tight association of the fragments is not mediated by disulfide bonding, but instead by noncovalent interactions that can be disrupted by boiling the NP40 extract with $0.2 \%$ SDS. Under these conditions, anti-NILE- $\beta$-gal immunoprecipitates only the $85 \mathrm{kDa}$ fragment. It is worth noting that, although there is no disulfide bonding between the 2 fragments, the conformation of the 160 $\mathrm{kDa}$ fragment appears to be stabilized by disulfide bonds. This is consistent with the evidence of Moos et al. (1988) that the extracellular domain of Ll contains immunoglobulin-like, disulfide-bonded domains.

Having established that the antigenic determinant recognized by anti-NILE- $\beta$-gal is found in the $85 \mathrm{kDa}$ fragment, we can further pinpoint its location within this portion of NILE. Work in other laboratories has established that this region of the molecule contains a phosphorylated cytoplasmic domain (Salton et al., 1983b; Faissner et al., 1985; Sadoul et al., 1988). Our experiments indicate that the anti-NILE- $\beta$-gal determinant is located in this cytoplasmic domain. First, both immunoprecipitation and immunofluorescence experiments show that this determinant is not exposed on the surface of intact cells but is recognized only after cells are treated with detergent. The "buried" nature of the determinant is consistent with its being located in a cytoplasmic domain. Second, the slightly truncated, spontaneously released form of NILE contains neither the antigenic determinant nor the phosphorylated residue(s). This is compatible with the idea that the "secretion" phenomenon is associated with a proteolytic event that releases most of the molecule from the cell surface, leaving behind a small membrane-bound domain containing the anti-NILE- $\beta$-gal determinant. Although it is highly speculative in the absence of additional sequence information for the extracellular portion of NILE, it is possible that the cytoplasmic portion may be more highly conserved than other parts of the molecule. The anti-NILE- $\beta$ gal antibody, which recognizes cytoplasmic determinants, immunoprecipitates not only rodent NILE, but also human NILE. In contrast, the anti-NILE antibody used in our experiments recognizes extracellular determinants of NILE and fails to immunoprecipitate the molecule from the human cell line IMR32. These extracellular determinants of NILE thus appear to be less highly conserved than the cytoplasmic determinant, which, as we have seen in Figure 2, is virtually identical in mouse and rat. An unusually high degree of sequence conservation has previously been observed in the cytoplasmic domains of the T200 glycoprotein (Thomas et al., 1985; Ralph et al., 1987; Raschke, 1987) and the $\beta$-subunit of the fibronectin receptor (Tamkun et al., 1986; Argraves et al., 1987). This would suggest an important function for the cytoplasmic portion of these transmembrane molecules, possibly in mediating interactions with the cytoskeleton.

The spontaneous release of NILE from the cell surface may be peculiar to cloned cell lines, since it is not observed with neurons in primary culture. However, release of NILE can be induced in primary cultures under certain conditions (Sweadner, 1983; Sadoul et al., 1988), producing the same type of soluble, truncated NILE described in our results. If a proteolytic event is indeed responsible for this "secretion" of NILE, it may be that cell lines have unusually high levels of the necessary proteolytic enzyme.
A simple model, patterned after that proposed for $\mathrm{Ll}$ by Sadoul et al. (1988), can be used to illustrate the major structural features of NILE (Fig. 8). The data from Schachner's laboratory indicate that the shorter, phosphorylated tryptic fragment of L1 represents the carboxy terminus of the molecule, while the larger, nonphosphorylated fragment contains the amino terminus (see Faissner et al., 1985; Moos et al., 1988). The site of trypsin cleavage is indicated by the arrow, splitting NILE into fragments of 160 and $85 \mathrm{kDa}$. The closed loop in the polypeptide represents the site of strong, noncovalent interaction between the 2 domains, while the 2 open loops in the $160 \mathrm{kDa}$ domain are shown to be stabilized by disulfide bonds. The number of disulfides chosen is purely arbitrary and is not based on experimental determination. The $\mathrm{L} 1$ glycoprotein appears to have 6 such disulfide-bonded domains (Moos et al., 1988). The arrowhead identifies the hypothetical site of proteolysis, which leads to spontaneous release of truncated, soluble NILE from the cell surface. Our nucleotide sequence data show that NILE-1B codes for the carboxy terminal region of NILE. In agrcement with this, our immunochemical evidence indicates that the epitope recognized by anti-NILE- $\beta$-gal must be located within the cytoplasmic domain at the carboxy terminal end of the molecule. This domain is not exposed on the cell surface and is left behind during the "secretion" of soluble NILE.

\section{References}

Amano, T., E. Richelson, and M. Nirenberg (1972) Neurotransmitter synthesis by neuroblastoma clones. Proc. Natl. Acad. Sci. USA 69: $258-263$.

Argraves, W., S. Suzuki, H. Arai, K. Thompson, M. Pierschbacher, and E. Ruoslahti (1987) Amino acid sequence of the human fibronectin receptor. J. Cell. Biol. 105: 1183-1190.

Beasley, L., and W. Stallcup (1987) The nerve growth factor-inducible large external (NILE) glycoprotein and neural cell adhesion molecule (N-CAM) have distinct patterns of expression in the developing rat central nervous system. J. Neurosci. 7: 708-715.

Bock, E., C. Richter-Landsberg, A. Faissner, and M. Schachner (1985) Demonstration of immunochemical identity between the nerve growth factor inducible large external (NILE) glycoprotein and the cell adhesion molecule L1. EMBO J. 4: 2765-2768.

Boulter, J., K. Evans, D. Goldman, G. Martin, D. Treco, S. Heinemann, and J. Patrick (1986) Isolation of a cDNA clone coding for a possible neural nicotinic acetylcholine receptor alpha-subunit. Nature 319: 368-374.

Daniloff, J., C.-M. Chuong, G. Levi, and G. Edelman (1986) Differential distribution of cell adhesion molecules during histogenesis of the chick nervous system. J. Neurosci. 6: 739-758.

Faissner, A., J. Kruse, C. Goridis, E. Bock, and M. Schachner (1984a) The ncural cell adhesion molecule Ll is distinct from the N-CAMrelated group of surface antigens BSP-2 and D2. EMBO J. 3: 733737.

Faissner, A., J. Kruse, J. Nieke, and M. Schachner (1984b) Expression of neural cell adhesion molecule L1 during development, in neurological mutants, and in the peripheral nervous system. Dev. Brain Res. 15: 69-82.

Faissner, A., D. Teplow, D. Kubler, G. Keilhauer, V. Kinzel, and M. Schachner (1985) Biosynthesis and membrane topography of the neural cell adhesion molecule L1. EMBO J. 4: 3105-3113.

Friedlander, D., M. Grumet, and G. Edelman (1986) Nerve growth factor enhances expression of neuron-glia cell adhesion molecule in PC12 cells. J. Cell. Biol. 102: 413-419.

Greene, L., and A. Tischler (1976) Establishment of a noradrenergic clonal line of rat pheochromocytoma cells which respond to nerve growth factor. Proc. Natl. Acad. Sci. USA 73: 2424-2428.

Grumet, M., S. Hoffman, and G. Edelman (1984a) Two antigenically related neuronal cell adhesion molecules of different specificities mediate neuron-neuron and neuron-glia adhesion. Proc. Natl. Acad. Sci. USA 81: 267-271. 
Grumct, M., S. Hoffman, C.-M. Chuong, and G. Edelman (1984b) Polypeptide components and binding functions of neuron-glia cell adhesion molecules. Proc. Natl. Acad. Sci. USA 81: 7989-7993.

Hoffman, S., D. Friedlander, C.-M. Chuong, M. Grumet, and G. Edelman (1986) Differential contributions of Ng-CAM and N-CAM to cell adhesion in different neural regions. J. Cell. Biol. 103: 145-158.

Hubbard, A., and Z. Cohn (1972) The enzymatic iodination of the red cell membrane. J. Cell. Biol. 55: 390-405.

Huynh, T., R. Young, and R. Davis (1985) Constructing and screening cDNA libraries in $\lambda \mathrm{gt} 10$ and $\lambda \mathrm{gt} 11$. In DNA Cloning, Vol. $1, \mathrm{~A}$ Practical Approach, pp. 49-78, IRC Press, Oxford, UK.

Keilhauer, G., A. Faissner, and M. Schachner (1985) Differential inhibition of neurone-neurone, neurone-astrocyte, and astrocyte-astrocyte adhesion by L1, L2, and N-CAM antibodies. Nature 316: 728-730

Laemmli, U. (1970) Cleavage of structural proteins during the assembly of the head of bacteriophage T4. Nature 225: 680-685.

Maniatis, T., E. Fritsch, and J. Sambrook (1982) Molecular Cloning: A Laboratory Manual, Cold Spring Harbor Laboratory, Cold Spring Harbor, NY.

McGuire, J., L. Greene, and A. Furano (1978) NGF stimulates incorporation of fucose or glucosamine into an external glycoprotein in cultured rat per pheochromocytoma cells. Cell 15: 357-365.

Moos, M., R. Tacke, H. Scherer, D. Teplow, K. Früh, and M. Schachner (1988) Neural adhesion molecular Ll is a member of the immunoglobulin super family with binding domains similar to fibronectin. Nature 334: 701-703.

Ralph, S., M. Thomas, C. Morton, and I. Trowbridge (1987) Structural variants of human T200 glycoprotcin (lcukocytc-common antigen). EMBO J. 6: 1251-1257.

Raschke, W. (1987) Cloned murine T200 (Ly-5) cDNA reveals multiple transcripts within B- and T-lymphocyte lineages. Proc. Natl. Acad. Sci. USA 84: 161-165.

Rathjen, F., and U. Rutishauser (1984) Comparison of two cell surface molecules involved in neural cell adhesion. EMBO J. 3: 461-465.

Rathjen, F., and M. Schachner (1984) Immunocytological and biochemical characterization of a new neuronal cell surface component (L1 antigen) which is involved in cell adhesion. EMBO J. 3:1-10.

Richter-Landsberg, C., V. Lee, S. Salton, M. Shelanski, and L. Greene (1984) Release of the NILE and other glycoproteins from cultured PC12 rat pheochromocytoma cells and sympathetic neurons. J. Neurochem. 43: 841-848.

Sadoul, K., R. Sadoul, A. Faissner, and M. Schachner (1988) Biochemical characterization of different molecular forms of the neural cell adhesion molecule L1. J. Neurochem. 50:510-521.

Sajovic, P., E. Kouvelas, and E. Trenkner (1986) Probable identity of the NILE glycoprotein and the high molecular weight component of L1 antigen. J. Neurochem. 47: 541-546.

Sajovic, P., D. Ennulat, M. Shelanski, and L. Greene (1987) Isolation of NILE glycoprotein-related cDNA probes. J. Neurochem. 49: 756763.
Salton, S., C. Richter-Landsbcrg, L. Grecne, and M. Shclanski (1983a) Nerve growth factor-inducible large external (NILE) glycoprotein: Studies of a central and peripheral neuronal marker. J. Neurosci. 3: $441-454$

Salton, S., M. Shelanski, and L. Greene (1983b) Biochemical properties of the nerve growth factor-inducible large external (NILE) glycoprotein. J. Neurosci. 3: 2420-2430.

Schubert, D., S. Heinemann, W. Carlisle, H. Tarikas, B. Kimes, S. Patrick, J. Steinbach, W. Culp, and B. Brandt (1974) Clonal cell lines from the rat central nervous system. Nature 249: 224-227.

Stallcup, W., and L. Beasley (1985a) Involvement of the nerve growth factor inducible large external (NILE) glycoprotein in neurite fasciculation in primary cultures of rat brain. Proc. Natl. Acad. Sci. USA 82: $1276-1280$

Stallcup, W., and L. Bcaslcy (1985b) Polymorphism among NILErelated glycoproteins from different types of neurons. Brain Res. 346: 287-293.

Stallcup, W., L. Arner, and J. Levine (1983) An antiserum against the PC12 cell line defines cell surface antigens specific for neurons and Schwann cells. J. Neurosci. 3: 53-68.

Stallcup, W., L. Beasley, and J. Levine (1985) Antibody against nerve growth factor inducible large external (NILE) glycoprotein labels nerve fiber tracts in the developing rat nervous system. J. Neurosci. 5: 10901101.

Sweadner, K. (1983) Post-translational modification and evoked release of two large surface proteins of sympathetic neurons. J. Neurosci. 3: 2504-2517.

Tacke, R., M. Moos, D. Teplow, K. Früh, H. Scherer, A. Bach, and M. Schachner (1987) Identification of $\mathrm{cDN} \Lambda$ clones of the mouse neural cell adhesion molecule L1. Neurosci. Lett. 82: 89-94.

Tamkun, J., D. DeSimmone, D. Fonda, R. Patel, C. Buck, A. Horwitz, and R. Hynes (1986) Structure of integrin, a glycoprotein involved in the transmembrane linkage between fibronectin and actin. Cell 46: $271-282$

Thiery, J.-P., A. DeLouvee, M. Grumet, and G. Edelman (1985) Initial appearance and regional distribution of the neuron-glia cell adhesion molecule in the chick embryo. J. Cell. Biol. 100: 442-456.

Thomas, M., A. Barclay, J. Gagnon, and A. Williams (1985) Evidence from cDNA clones that the rat leukocyte-common antigen (T200) spans the lipid bilayer and contains a cytoplasmic domain of 80,000

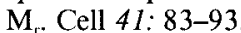

Towbin, H., T. Staehelin, and J. Gordon (1979) Electrophoretic transfcr of protcins from polyacrylamide gcls to nitrocellulose shects: Procedure and some applications. Proc. Natl. Acad. Sci. USA 76: 43504354.

Tumilowicz, J., W. Nichols, J. Cholon, and A. Green (1970) Definition of a continuous human cell line derived from neuroblastoma. Cancer Res 30: $2110-2118$ 